\title{
Determination and Mapping of the Relationship between Potassium and Ammonium of Calcareous Soils with Different Moisture Content
}

\author{
Emrah Ramazanoglu \\ Department of Soil Science and Plant Nutrition, Agriculture Faculty of Harran University, \\ Osmanbey Campus, Sanliurfa, Turkey \\ E-mail: ramazanoglu@harran.edu.tr \\ ORCID: 0000-0002-7921-5703
}

\begin{abstract}
The aim of this study was to determine the conditions of potassium $\left(\mathrm{K}^{+}\right)$and the inorganic form of nitrogen $\left(\mathrm{NH}_{4}^{+}\right)$, and to map their current status using geographic information systems, in calcareous soils with different moisture content. Potassium in the soil is in exchangeable, soluble and nonchangeable forms. Because the ions are fixed by the same mechanism, their release might be expected to be somewhat similar so, it has been suggested that $\mathrm{NH}_{4}{ }^{+}$and $\mathrm{K}^{+}$ions are fixed in soils. This study was carried out in the field of Horticulture Fruit Research Unit (AR-GE) in Osmanbey Campus at Harran University. Mean concentrations were evaluated which soils were extracted in dry and moisture conditions respectively. The average concentration was determined $\mathrm{K}^{+} 362$ and $\mathrm{NH}_{4}{ }^{+} 98 \mathrm{ppm}$ in dry soil while were $\mathrm{K}^{+} 258, \mathrm{NH}_{4}{ }^{+} 50.26 \mathrm{ppm}$ in moisture soil. Ammonium and potassium in soil were detected to be lower concentrations in moisture than dry conditions.
\end{abstract}

Key words: Ammonium, potassium, CBS, moisture soil, jeostatistic.

DOI: $10.7176 / \mathrm{JSTR} / 5-7-03$

\section{Farklı Nem İçeriğine Sahip Kireçli Toprakların Potasyum ve Amonyum İlişkisinin Belirlenmesi ve Haritalanması}

\begin{abstract}
Özet
$\mathrm{Bu}$ çalışmanın amacı farklı nem içeriğine sahip kireçli topraklarda Potasyum $\left(\mathrm{K}^{+}\right)$ve azotun inorganik formu olan Amonyum $\left(\mathrm{NH}_{4}{ }^{+}\right)$durumlarının tespiti ve coğrafi bilgi sistemleri kullanılarak mevcut durumlarının haritalanması amaçlanmıştır. Toprakta potasyum değişebilir, çözünebilir ve değişemez formlarda bulunmaktadır. Bu iki katyon aynı iyonik çap ve yüke sahip oldukları için benzer mekanizma ile toprakta tutulmaktadır. Bu çalışma Harran Ovasının kuzey noktasında yer alan Harran Üniversitesi Osmanbey kampüsünde bulunan Bahçe Bitkileri AR-GE alanında yürütülmüştür. Topraklar sırası ile kuru ve nemi koşullarda ekstrakte edilerek ortalama konsantrasyonları değerlendirilmiştir. Kuru toprakta ortalama konsantrasyon olarak $\mathrm{K}^{+} 362, \mathrm{NH}_{4}{ }^{+} 98$ ppm olarak tespit edilirken, nemli toprakta ise ortalama $\mathrm{K}^{+} 258, \mathrm{NH}_{4}^{+} 50.26$ ppm olarak belirlenmiştir. Nemli toprak koşullarında $\mathrm{NH}_{4}^{+}$ve $\mathrm{K}^{+}$kuru koşullara göre daha düşük konsantrasyonlarda olduğu belirlenmiştir.
\end{abstract}

Anahtar kelimeler: Amonyum, Potasyum, CBS, Nemli Toprak, jeoistatistik

\section{Giriş}

Potasyumun $\left(\mathrm{K}^{+}\right)$toprakta tutulması veya tekrar yarayışlı forma dönüşmesi için meydana gelen olayların tam anlamıyla daha aydınlatılmadığı belirtilmektedir. Topraktaki $\mathrm{K}^{+}$' toprağın tekstürel yapıs1, organik karbon, donma-çözünme ve ıslanma-kuruma, kireç ve pH gibi toprak özelliklerinin etkilediği bilinmektedir (Bilen ve Sezen, 1993). Potasyumun hangi pH koşullarında tutulduğu kesin olarak bilinmemesine rağmen genel olarak yüksek $\mathrm{pH}$ koşullarında $\mathrm{K}^{+}$'un tutulduğu kabul 
edilmektedir. Bazik topraklarda $\mathrm{K}^{+}$daha fazla tutulurken, $\mathrm{pH}$ 'ın çok düşük olduğu topraklarda, $\mathrm{Fe}, \mathrm{Al}$ ve $\mathrm{H}$ ile rekabeti zayıf olduğundan tutulması da zayıftır. Toprak reaksiyonunun yükselmesi ile kolloidal yüzeylerden $\mathrm{Fe}$, Al ve $\mathrm{H}$ uzaklaşmakta ve bunların yerine $\mathrm{K}^{+}$'un geçtiği kabul edilmektedir (Sezen, 1975; 1991; Ünal ve Başkaya, 1981). Bu da negatif yüklerin artmasına bağlamıştır (Tisdale ve Nelson, 1985). Yüksek alkali koşulların $\mathrm{K}^{+}$alımına ters etkisini ilginç bir şekilde ifade ederken, yüksek pH'larda $\mathrm{Ca}^{+2}$ topraktaki bakteri aktivitesini artırarak $\mathrm{K}^{+}$un yarayışsız kalmasına neden olduğunu bildirmiştir (Çeçen, 1962). Mardin Mazıdağı bölgesinde yapılan bir çalışmada da toprakların C:N oranlarının düşüklüğünü bakteri aktivitesinin yüksek olmasına bağlı olduğunu belirtmişlerdir (Abak ve Sakin, 2018).

Toprakta azotun inorganik formu olarak bulunan amonyum $\left(\mathrm{NH}_{4}^{+}\right)$toprakların aktif kısmını oluşturan kil minerallerinin kristal kafes yapısı içerisinde tutulmaktadır (Sezen, 1991). Kil tipi ve çeşidi $\mathrm{NH}_{4}{ }^{+}$ tutulması üzerinde son derece etkili olmaktadır. Killi tınlı tekstüre sahip topraklar siltli tınlı tekstürlü topraklara göre amonyumu daha fazla fikse etmektedir. Aynı şekilde siltli tınlı tekstürlü topraklar da kumlu topraklara göre daha fazla amonyumu tutmaktadır. Toprakta tutulan amonyum miktarı fiksasyonu gerçekleştiren materyalin tabiatına bağlı olarak değişir. 2:1 tipi kil minerallerinin baskın olduğu topraklarda $\mathrm{K}^{+}$ve $\mathrm{NH}_{4}^{+}$1:1 tipi killere (kaolonit) göre daha fazla fikse edildiği belirtilmiştir (Neider ve ark., 2011). Toprak rutubetinin amonyum fiksasyonunu azalttığını, kil minerallerinin sslak koşullarda genişlediğini bildirmişlerdir. Ayrıca araştırıcılar kuru topraklarda tabakalar arasının daraldığını ve tutulan amonyumu da arttığını bildirmişlerdir (Allison ve ark., 1953).

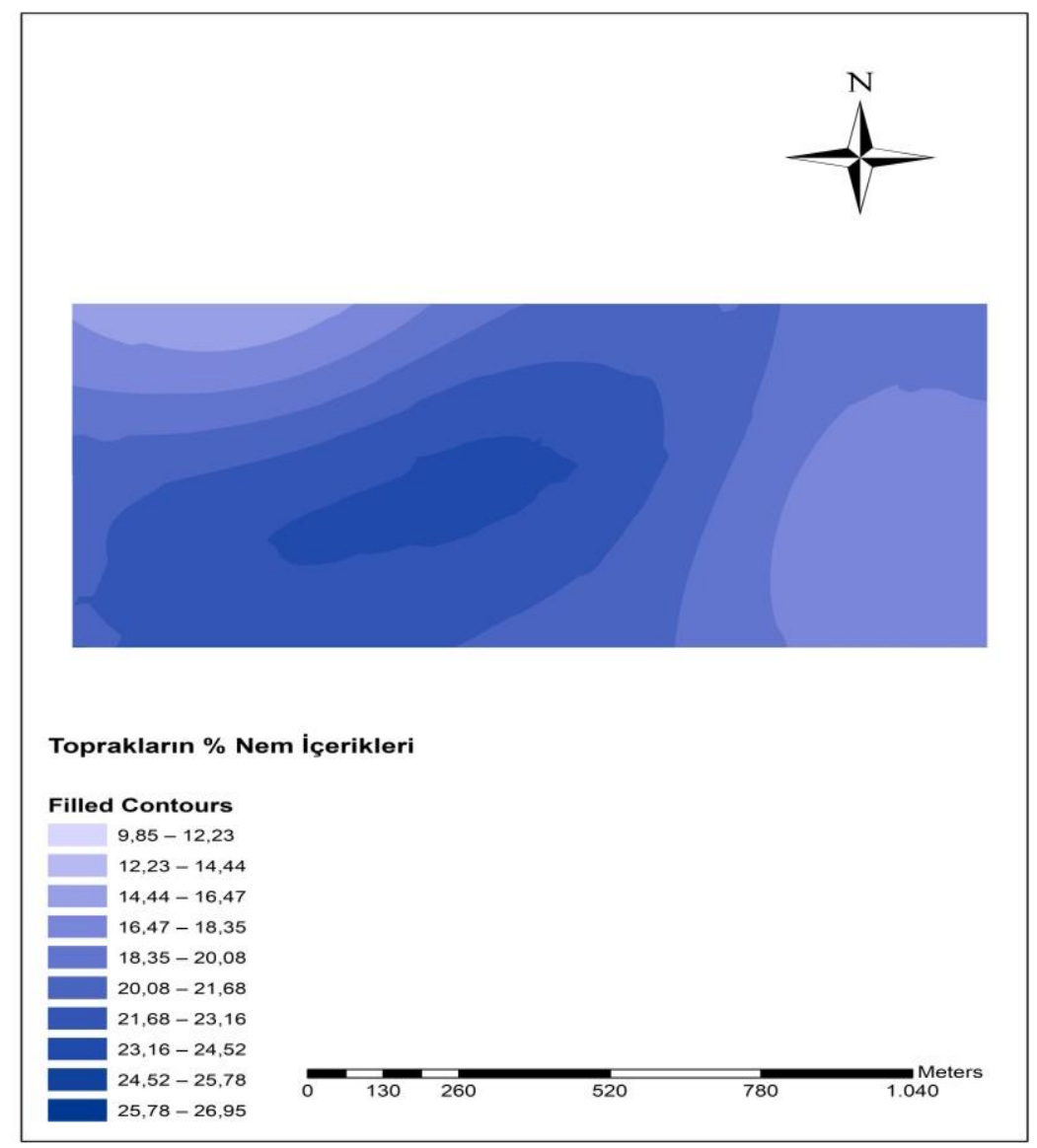

Resim 1. Çalışma alanına ait nem içeriklerinin dağılımı

Topraklarda $\mathrm{NH}_{4}{ }^{+}$fiksasyonu çok hızlı bir şekilde cereyan etmektedir. Amonyum toprağa uygulandıktan sonra 6 saat içinde \%50'sinin fikse edildiği belirtmişlerdir. Ancak fikse edilen $\mathrm{NH}_{4}{ }^{+}$ yavaş yavaş serbestlediği ifade etmişlerdir. Amonyumun toprakta serbestleme hızı fiksasyon hızından daha yavaş olduğu belirtilmiştir (Drury ve Beauchamp, 1991). Kowalenko (1989) toprağa uygulanan amonyumun \%36'sının killer tarafından hızla fikse edildiğini ve arazide 14 gün sonra bu oranın $\% 1$ 'den daha az olduğunu ifade etmişlerdir. (Sowden ve ark. 1978) amonyum fiksasyonunun \%43- 
55'inin 2 saat içinde tamamlandığ belirtmişlerdir.

Amonyumun ve $\mathrm{K}^{+}$'un toprakta tutulması veya yeniden serbest hale geçmesi kil minerallerinin yapısı ile ilgili olup, $\mathrm{K}^{+}, \mathrm{NH}_{4}^{+}$ve diğer monovalan (tek değerlikli) katyonların divalan (çift değerlikli) katyonlar kadar fiksetme kabiliyetine bağlı olduğu belirtmiştir. Değişebilir $\mathrm{K}^{+}$ve $\mathrm{NH}_{4}{ }^{+}$katyonları kil ve humus kolloidlerinin yüzeyine tutunmuş adsorbe formda da bulunabilirler. Ancak fikse edilmiş $\mathrm{K}^{+}$ve $\mathrm{NH}_{4}{ }^{+}$iyonları ise kil minerallerinin özellikle illit, montmorillonit ve vermikülitin tabakaları arasına hapsolmuşlardır. Toprakların $\mathrm{K}^{+}$ve $\mathrm{NH}_{4}{ }^{+}$fiksasyon kapasitesi kil minerallerine bağlı olup kuru şartlardaki fiksasyon sslak şartlardakinden daha yüksek düzeylerdedir (Erdil ve ark., 2018).

Coğrafi bilgi sistemleri kullanılarak yoğun tarımsal üretim yapılan alanların etkin kullanımını ve sürdürülebilirliğinin yönetiminde büyük kolaylıklar sağlamaktadır. Toprakların fiziksel, kimyasal ve biyoloji olarak sınıflandırılması toprak kalitesi açısından birçok parametreyi tek bir çerçeveden görme ve yorumlayabilme gibi önemli firsatlar sunmaktadır. Hanway ve Scott (1957), farklı Iowa topraklarının profillerinden aldıkları toprak örneklerinde nemli, hava kuru ve firın kuru olarak değişebilir K'u belirlemişlerdir. Araştırmacılara göre, kurutma işlemi bütün toprak örneklerinde değişebilir potasyumda artışa neden olmuştur.

\section{Materyal ve Metot}

Çalışma alanı $37^{\circ} 10^{\prime}$ 14" kuzey enlemleri ile 3900' 14" doğu boylamları arasında yer almaktadır. Topraklar kireç ana materyali üzerinde oluşmuş AC horizonlu, killi ve kireçli topraklar olup, kalsik Vertisoller grubuna girmektedir (IUSS, 2014). Toprak örnekleri 0-20 cm toprak derinliğinde 20 adet alınmıştır. Alınan örnekler buzdolabında $+4{ }^{\circ} \mathrm{C}$ 'de muhafaza edilmiş ve gerektiğinde kullanılmıştır. Çalışma alanından alınan toprak örneklerine ait noktalar harita üzerinde belirtilmiştir (Resim 2).

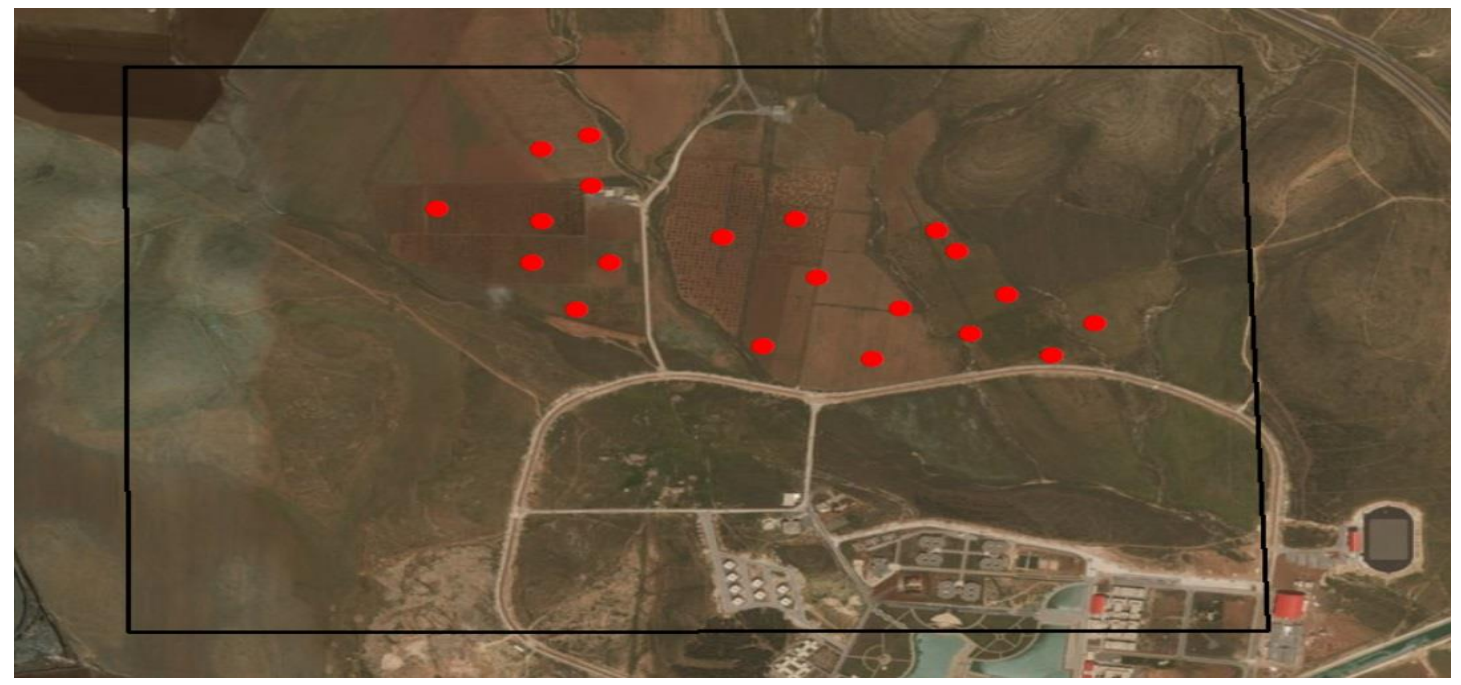

Resim 2. Toprak örneklerinin alındığı noktalar

Harran ovası kuzey kesimi yazları kurak ve sıcak, kışları 1lık ve az yağışı geçmektedir. Bazı yıllarda düşen yağış tarımsal üretim için yeterli değildir. Yıllık ortalama yağış $448.11 \mathrm{~mm}$ olup, yıllık ortalama en yüksek sıcaklık $41.12{ }^{\circ} \mathrm{C}$ Temmuz, en düşük sıcaklık $2.41{ }^{\circ} \mathrm{C}$ Şubat ayında görülmüştür. Yıllık ortalama bağıl nem en yüksek \%92.32 en düşük \%33.29 olarak belirlemişlerdir. (Sakin ve Yanardağ, 2019)

Çalışma topraklarında bünye analizi Bouyoucos (1951)'un hidrometre metoduyla, pH tayini Black (1965)'in bildirdiği şekilde, toplam tuz Tüzüner (1990)'e, kireç analizi Gülçur (1974) ve organik madde tayini Nelson ve Sommers (1996)'ın yaş yakma metoduna göre gerçekleştirilmiştir. Değişebilir katyonlar Helmke ve Sparks (1996), İnorganik $\mathrm{NH}_{4}$ (amonyum) Azotu Keeney ve Bremner (1966) göre belirlenmiştir. Katyon değişim kapasitesi Bower (1952) tarafından bildirildiği şekilde yapılmıştır. ArcGIS yazılımı kullanılarak 1/250 000 ölçekli jeoistatistiksel olarak toprak dağılım haritaları elde edilmiştir. 


\section{Araştırma Bulguları ve tartışma}

Çalışma alanından alınan toprak örnekleri için fiziksel ve kimyasal analizler yapılmıştır. Çalışma alanına ait toprakların fiziksel ve kimyasal analiz sonuçları verilmiştir (çizelge 1).

Çizelge 1. Çalışma alanı ait toprakların fiziksel ve kimyasal analiz sonuçları

\begin{tabular}{llcccl}
\hline $\mathrm{pH}$ & $\mathrm{Tuz}$ & $\mathrm{CaCO}_{3}$ & $\mathrm{O}$ & $\mathrm{KDK}$ & Bünye \\
\hline & $(\mathrm{mmhos} / \mathrm{cm})$ & $\%$ & $\%$ & $\mathrm{Cmol} / \mathrm{kg}$ & \\
\hline $\mathbf{7 . 3 0}$ & $\mathbf{1 . 1 7}$ & 31.52 & 2.05 & 38.5 & $\mathrm{CL}$ \\
\hline
\end{tabular}

Çizelge 2. Toprak örneklerinin tanımlayıcı istatistik sonuçları

\begin{tabular}{|l|c|c|c|c|}
\hline Parametreler & En düşük & En yüksek & Ortalama & Standart sapma \\
\hline Toprak Nemi & 11,09 & 13,69 & 12,47 & 0,69 \\
\hline Nemli Toprakta K+ & 180,00 & 340,00 & 258,00 & 45,60 \\
\hline Kuru Toprakta K+ & 300,00 & 450,00 & 362,00 & 42,25 \\
\hline Kuru Toprakta $\mathrm{NH}_{4}^{+}$ & 70,00 & 126,00 & 98,00 & 20,81 \\
\hline Nemli Toprakta $\mathrm{NH}_{4}^{+}$ & 14,00 & 98,00 & 50,26 & 22,35 \\
\hline
\end{tabular}

Yapılan esktraksiyon işlemleri sonucunda (çizelge 2.) nemli toprak örneklerinin ortalama $\mathrm{K}^{+}$ konsantrasyonlar1 $258 \mathrm{ppm}$ olarak belirlenirken, $\mathrm{NH}_{4}{ }^{+}$konsantrasyonları $50.26 \mathrm{ppm}$ olarak belirlenmiștir. Kuru toprak örneklerinin ortalama $\mathrm{K}^{+}$konsantrasyonları $362 \mathrm{ppm}$ iken $\mathrm{NH}_{4}^{+}$ konsantrasyonları $98 \mathrm{ppm}$ olarak saptanmıştır. Hem kuru toprakta hem de 1slak toprakta $\mathrm{K}^{+}$ konsantrasyonu $\mathrm{NH}_{4}{ }^{+}$ya göre daha baskın olduğu görülmüştür. Yani toprak kuru da olsa 1slakta olsa toprakta daha fazla $\mathrm{K}^{+}$konsantrasyonu olduğu belirlenmiştir. Nemli topraklarda $\mathrm{K}^{+} \mathrm{NH}_{4}{ }^{+}$'a göre daha fazla tutulduğu ve bu tutulma kil minerallerinin tipine ve miktarına göre değiştiğini ifade etmişlerdir (Jensen ve ark., 1989; Feigenbaum, 1994). Bu iki iyonun toprakta ve kil minerallerinde ayn1 mekanizma ile tutulmaktadır (Levine ve Joffe., 1947; Peech ve Bradfield., 1943). Bu mekanizmada aralarında doğrusal bir ilişki durumu söz konusu olduğu öne sürülmüştür. Bu durum ilk tutulan iyonun diğer iyonun tutulmasını engellediği fikrine dayanmaktadır. Bu fikirde bu iyonların iyonik çaplarının aynı olmasından kaynaklanmaktadır (Levine, 1947; Pierre., 1947).

Harran ovasının kuzey kesiminde yer alan topraklar kurak ve yarı kurak iklim bölgesinde bulunması nedeni ile toprakların $\mathrm{K}^{+}$konsantrasyonu $\mathrm{NH}_{4}{ }^{+}$göre daha fazla saptanmıştır. Toprakta $\mathrm{N}$ miktarı az olup, büyük bir kısmı organik formda bulunmaktadır. Bu form içinde bulunan azotun mineralize olması çeşitli faktörlere (toprak sıcaklığı, nem ve oksijen) bağlı olup, uzun bir zamana ihtiyaç vardır.

Potasyum topraktaki nem içeriğine bağlı olarak üç formda bulunmaktadır. Bu formlar kimyasal olarak denge durumundadır. Herhangi bir formun çıkarılması veya eklenmesi dengenin değişmesine neden olur. Yapılan çalışmalarda $\mathrm{NH}_{4}$ 'un da benzer bir kimyasal değişim gösterdiğini ifade etmişlerdir (Kuchenbuch ve ark., 1986).

Amonyum tutulması kil mineralleri tarafından amonyumun uyguladıktan hemen sonra fikse edildiği ve bunun killi topraklarda daha fazla olduğu bildirmişlerdir. Vermikulit kapsamı yüksek topraklarda 15 günlük inkübasyondan sonra ilave edilen amonyumun \%18-23'ünün fikse edildiği bildirilmiştir (Chantigny ve ark., 2004). Toprak neminin $\mathrm{NH}_{4}{ }^{+}$fiksasyonunu azalttığını ve kil minerallerinin nemli koşullarda genişlediğini ifade etmişlerdir. Araştırıcılar kuru topraklarda tabakalar arasının daralması nedeni ile fikse edilen $\mathrm{NH}_{4}{ }^{+}$miktarının arttığını bildirmişlerdir (Allison ve ark., 1953). 


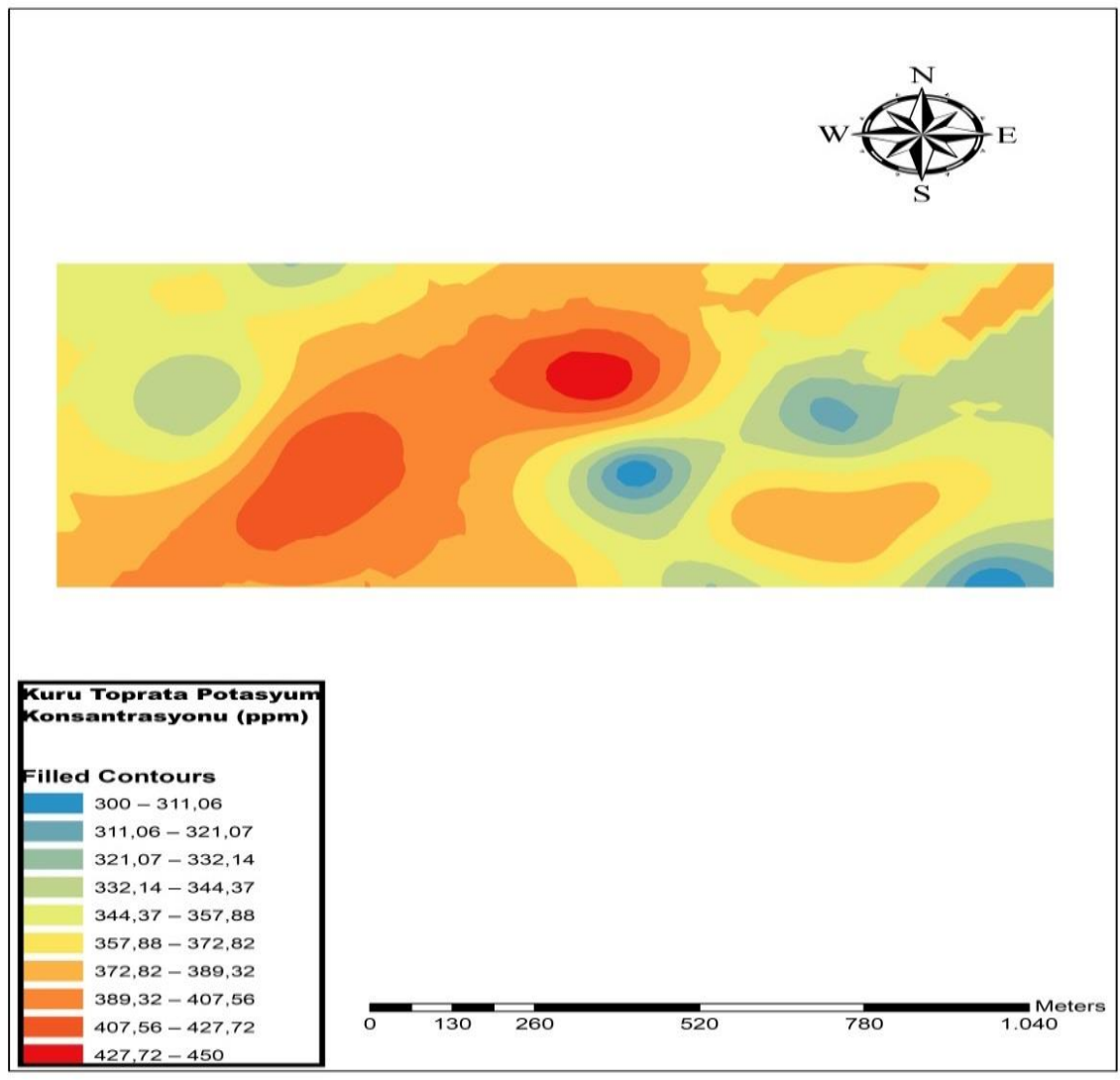

Resim 3. Çalışma alanının Kuru toprak koşullarında potasyum konsantrasyonu dağı̆lımı

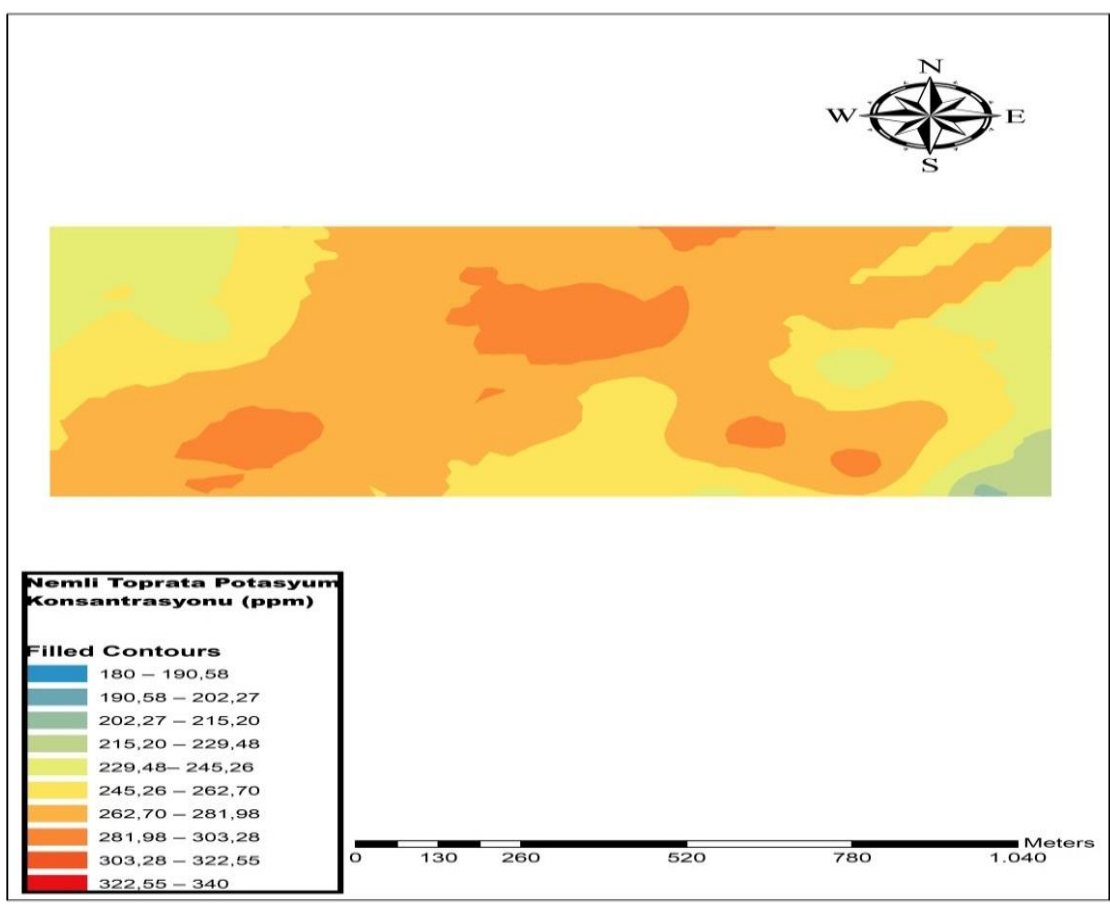

Resim 4. Çalışma alanının nemli toprak koşullarında potasyum konsantrasyonu dağı̆ımı 
Toprakta değişebilir $\mathrm{K}^{+}$ve $\mathrm{NH}_{4}$ miktarları ile nem arasındaki korelasyon ilişkisi (Çizelge 3) verilmiştir. Buna göre toprakta nem artıkça değişebilir $\mathrm{K}+$ miktarı artarken, $\mathrm{NH}_{4}{ }^{+}$miktarı azalmaktadır $(\mathrm{p}<0.01$; $\left.\mathrm{r}^{2}: 0.78\right)$. Değişebilir K miktarına bakıldığında gerek kuru toprakta olsun gerekse nemli toprakta olsun her iki durumda da artmıştır. Bu da her iki durumda da K'un NH4+ baskıladığını göstermiştir. Değişebilir K'un fazla olması NH4'un kil mineralleri tarafından daha fazla tutulduğu anlamına da gelmektedir (Neider ve ark., 2011). Smektit kil minerallerinin izomorfik yer değişimi nedeni ile daha fazla $\mathrm{NH}_{4}{ }^{+}$tutulduğu belirtmiştir. Özellikle izomorfik yer değişim olayının tetrahedron tabakada meydana gelmesi ile ilişkilendirmiştir (Feigenbaum, 1994). Bazı araştırmacılar ise nemli koşullarda katyon değişim kapasitesi artığı için $\mathrm{NH}_{4}{ }^{+}$tutulmasını artırdığını ifade etmişlerdir (Keerthisinghe, 1984; Chen ve ark., 1987; Phillips ve ark., 1998).

Barshad (1951), vermikulit'te ve toprakta tutulmuş olan NH4'u bir derece kadar Li, $\mathrm{Na}, \mathrm{Ca}, \mathrm{Mg}$ ve $\mathrm{Ba}$ ile değiştirilebileceği belirtmişlerdir. Toprakta bu elementlerin bulunması durumunda $\mathrm{NH}_{4}$ serbestlemesi artmaktadır.

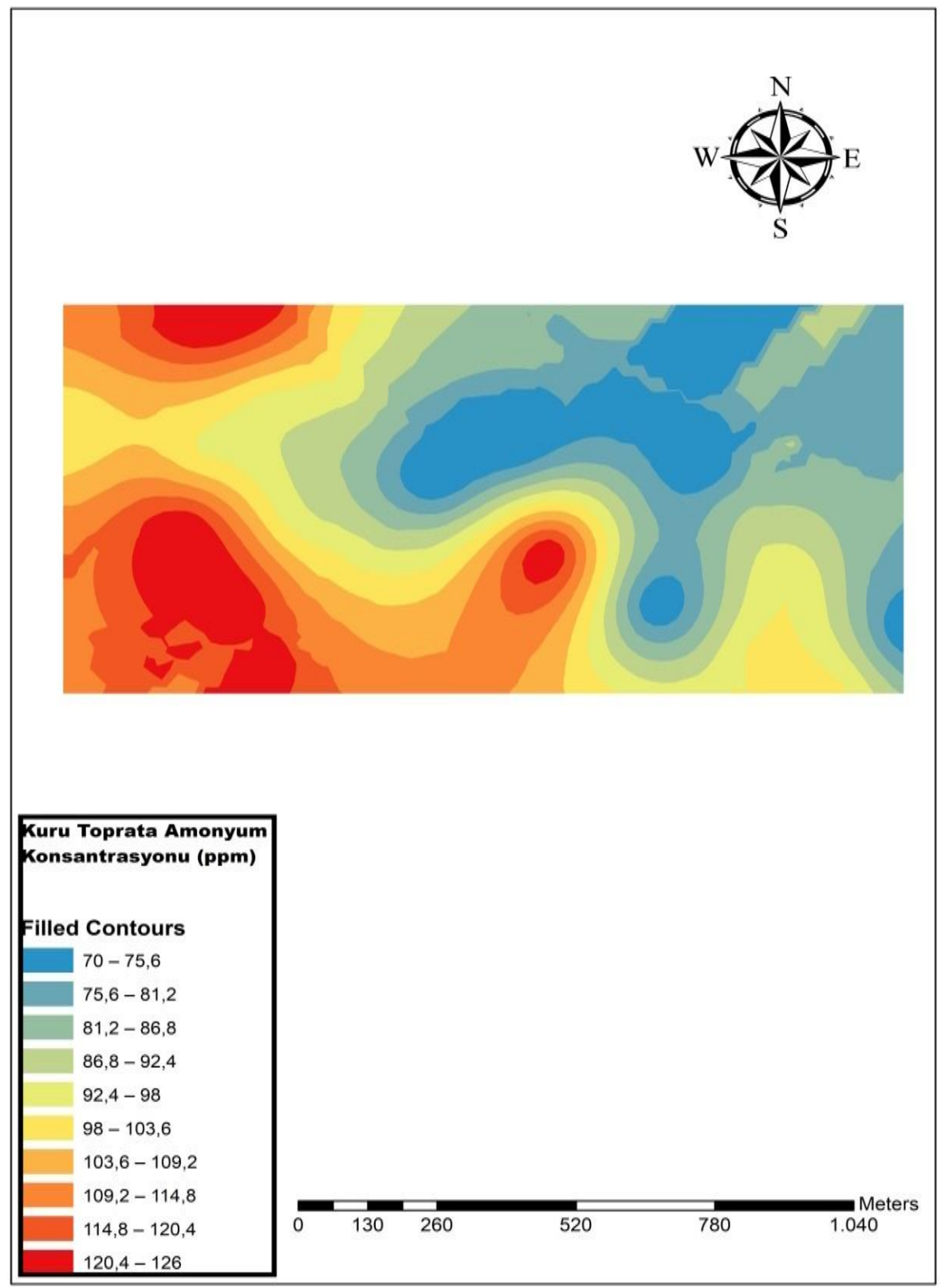

Resim 5. Çalışma alanının Kuru toprak koşullarında amonyum konsantrasyonu dağılımı 


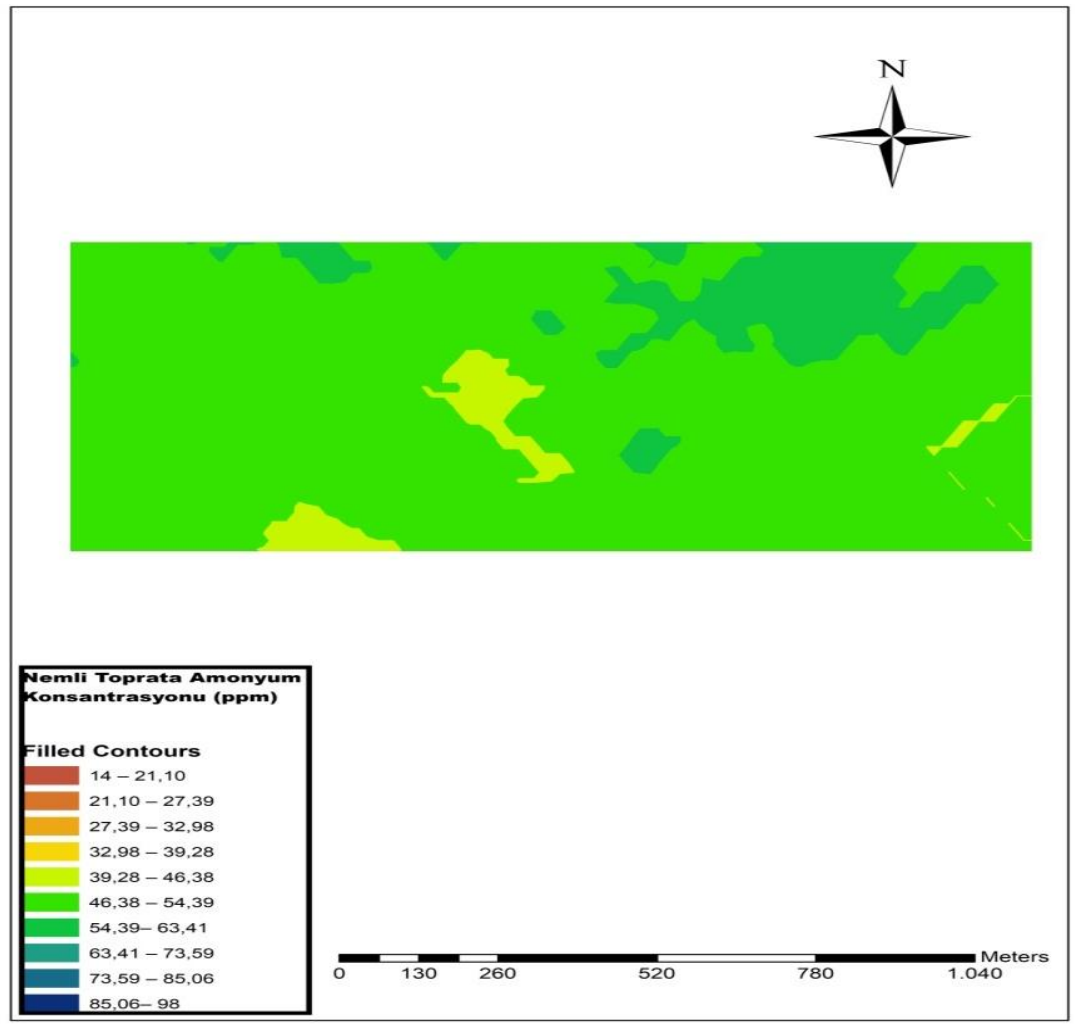

Resim 6. Çalışma alanının Nemli toprak koşullarında amonyum konsantrasyonu dağılımı

Çizelge 3. Parametreler arası korelasyon

\begin{tabular}{|l|c|c|c|c|c|}
\hline \multicolumn{2}{|c|}{ Parametreler } & $\begin{array}{c}\text { Nemli } \\
\text { Toprakta K }\end{array}$ & $\begin{array}{c}\text { Kuru } \\
\text { Toprakta K }\end{array}$ & $\begin{array}{c}\text { Kuru } \\
\text { Toprakta } \\
\mathrm{NH}_{4}^{+}\end{array}$ & $\begin{array}{c}\text { Nemli } \\
\text { Toprakta } \\
\mathrm{NH}_{4}^{+}\end{array}$ \\
\hline \multirow{3}{*}{ Toprak Nemi } & Pearson Correlation & 0,346 & $0,476^{*}$ & $-0,215$ & $-0,025$ \\
\cline { 2 - 6 } & Sig. (2-tailed) & 0,135 & 0,034 & 0,362 & 0,918 \\
\hline \multirow{2}{*}{ Nemli Toprakta K } & Pearson Correlation & & $0,778^{* *}$ & $-0,147$ & 0,271 \\
\cline { 2 - 6 } & Sig. (2-tailed) & & 0,000 & 0,535 & 0,247 \\
\hline \multirow{2}{*}{ Kuru Toprakta K ${ }^{+}$} & Pearson Correlation & & & $-0,184$ & 0,266 \\
\cline { 2 - 6 } & Sig. (2-tailed) & & & 0,437 & 0,256 \\
\hline \multirow{2}{*}{ Kuru Toprakta $\mathrm{NH}_{4}^{+}$} & Pearson Correlation & & & & 0,162 \\
\cline { 2 - 6 } & Sig. (2-tailed) & & & & 0,496 \\
\hline
\end{tabular}

Oktahedral tabakadaki yük artışı ve sıcaklık her iki iyonun tutulması üzerinde etkili olan parametrelerdir. Bölge topraklarının killi (smektit), kireçli olması ve organik karbon içeriğinin düşük olması nedeni ile NH4 iyonun düşük olmasına neden olmuştur (Chen ve ark., 1989). Toprakta NH4+ kapsamı, toprak ana materyaline, toprak tekstürüne, kil kapsamına, kil mineral kompozisyonuna, toprak çözeltisinde potasyum konsantrasyonuna, toprak kolloidlerinin potasyum doygunluk derecesine, 2:1 tipi kil minerallerinin tabakalarının potasyum doygunluğuna, toprak rutubet şartlarına bağlı olduğu belirtilmiştir (Nieder ve ark., 2011).

Potasyumun toprakta tutulması veya serbestlemesi topraktaki potasyumun dinamik yapısını; toprağın tekstürel yapısı, organik madde, donma-çözünme ve ıslanma-kuruma, kireç ve pH'nın etkilediği bilinmektedir. Toprakların kireç, $\mathrm{pH}$ ve diğer bazı özellikleri toprak potasyumunun serbest 
bırakılmasına veya tutulmasına etki ettiği bilinmektedir (Bilen ve Sezen 1993). Welch (1958)'de topraktaki değişebilir amonyum ve potasyum yine topraktaki $\mathrm{Na}$ tarafından engellendiğini saptamıştır.

\section{Sonuç ve Öneriler}

Yapılan araştırma sonucunda, kuru toprak koşullarında topraklarda tutulan potasyum miktarı konsantrasyon açısından amonyum miktarından daha yüksek olduğu belirlenmiştir. Bu durum çalışma alanı ile ilgili yapılan dağılım haritaları ile detaylı bir şekilde gözlemlenebilmektedir. Kuru toprak koşullarındaki potasyum konsantrasyonu ile nemli topraklardaki potasyum konsantrasyonları arasında ortalama konsantrasyon olarak birbirlerine yakın miktarlarda belirlenmiştir. Amonyum iyonu nemli topraklarda çok düşük miktarlarda adsorbe edilirken, kuru toprak koşullarında daha fazla tutulmaktadır. Harran ovası kuzey bölgesinde yer alan çalışma alanımızda kuru toprak ve nemli toprakta potasyum konsantrasyonu amonyum konsantrasyonundan daha yüksek olduğu belirlenmiştir. Toprakta tutulan potasyum ve amonyum miktarını belirlerken toprakların nemli ve kuru olmalarının yanında pek çok faktöre bağlıdır. Sodyum, Ca ve Mg içeriği yüksek olan topraklarda bu iki iyonun nasıl etkilendiği iyice saptanmalıdır. Tutulma işlemleri farklı kil tipleri ve farklı $\mathrm{pH}$ aralıklarında da bakılmalıdır.

\section{Kaynaklar}

Allison, F., M. Kefauver, and E. Roller, Ammonium Fixation in Soils 1. Soil Science Society of America Journal, 1953. 17(2): 107-110.

Abak, M., Sakin, E., 2018. Toprakların C:N Oranı ve Bazı Toprak Özellikleri İle İlişkisi: Mardin Mazıdağı Örneği. Harran Tarım ve Gıda Bilimleri Dergisi, 22 (2):255-261.

Barshad, I., 1951. Cation exchange in soils : I. Ammonium fixation and its relation to potassium fixation and to determination of ammonium exchange capacity. Soil Sci. 72: 361-371.

Bilen, S., Sezen, Y., 1993. Toprak Reaksiyonunun Bitki Besin Elementleri Elverişliliği Üzerine Etkisi. Ankara Ü. Zir. Fak. Der. 24 (2), 156-166.

Black, C.A., 1965. Methods of Analysis Agreon., No: 9, Ame. Soc. Agr. , Madison Wisconsin. USA.

Bouyocous, G.L., 1951. A Recalibration of Hydrometer Method for Making Mechanical Analysis of soils. Agronomy Journal $43 ; 434-438$

Chen R, Zhang J, Guo W, Chen, W. N fertilizer (urea) topdressed on unsaturated soil and deepplaced using reflooding water. Int Rice Res Newsl, 1987a. 12:35-36.

Chen, C.-C., F.T. Turner, and J.B. Dixon, Ammonium fixation by high-charge smectite in selected Texas Gulf Coast soils. Soil Science Society of America Journal, 1989. 53(4): p. 1035-1040.

Çeçen, K., 1962. Topraklarınızı Kireçleyiniz. Toprak Su Genel Müd. Neşriyatı, Sayı: 145,34-40.

Drury, C., E. Beauchamp, and L. Evans, Fixation and immobilization of recently added in selected Ontario and Quebec soils. Canadian journal of soil science, 1989. 69(2): p. 391-400.

Erdil, A., Horuz, A., Korkmaz, A., Güney Akınoğlu, G., 2018. Topraklarda Amonyum Fiksasyonu ve Etkileri. Int. Jouri of Life Sciences and Biotechn., 2018. 1(1): 17-28.

Feigenbaum, S., Clay-fixed labeled ammonium as a source of available nitrogen. Soil Science Society of America Journal, 1994. 58(3): p. 980-985.

Gülçur, F., 1974. Toprağın Fiziksel ve Kimyasal Analiz Metodları, İstanbul Üniversitesi Orman Fakültesi Yayınları, İ. Ü. Yayın No: 1970, Yayın No: 201, Kutulmuş Matbaası, İstanbul 
Hanway ve Scott ,1957. Soil Potassium-Moisture Relations: II. Profile Distribution of Exchangeable $\mathrm{K}$ in lowa Soils as Influenced by Drying and Rewetting.Soil Science Society and Anerica Journal, Vol. 21 No. 5, p. 501-504.

Helmke, P.A., Sparks, D.L., 1996. Lithium, Sodium, Potassium, Rubidium, and Calcium, in Sparks, D.L., (Ed) Methods of Soil Analysis, Part 3, Chemical Methods, SSSA Book Series Number 5, SSSA., Madison,WI, s. 551-574.

Jensen, E., B.T. Christensen, and L. Sørensen, Mineral-fixed ammonium in clay-and silt-size fractions of soils incubated with $15 \mathrm{~N}$-ammonium sulphate for five years. Biology and fertility of soils, 1989. 8(4): 298-302.

Keerthisinghe, G., K. Mengel, and S. De Datta, The Release of Nonexchangeable Ammonium (15N Labelled) in Wetland Rice Soils1. Soil Science Society of America Journal, 1984. 48(2): 291 294.

Keeney, D.R. ve Bremner, J.M.. 1966. Comparison and evaluation of laboratory methods of obtaining an index of soil nitrogen availability. Agron. J. 58: 498-503

Kuchenbuch, R., N. Claassen And A. Jungk., 1986. Potassium availability in relation to soil moisture. Plant and Soil 95,221-231

Kowalenko, C. and G. Ross, Studies on the dynamics of" recently" clay-fixed NH4+ using $15 \mathrm{~N}$. Canadian Journal of Soil Science, 1980. 60(1): 61-70.

Levine, A. K. Fixation of potassium in relation to the exchange capacity of soils : II. Association fixation of other cations, especially ammonium. Soil Sci. 63: 151-158. 1947.

Levine, A. K. and Joffe, J. S. 1947. Fixation of potassium in relation to exchange capacity of soils: V. Mechanism of fixation. Soil Sci. 63: 407-416.

Nelson, D.W., Sommers, L.E., 1996. Total Carbon, Organic Carbon, and Organic Matter. in D.L. Sparks (Ed) Methods of Soil Analysis, Part 3, Chemical Methods, SSSA Book Series Number 5, SSSA., Madison,WI, s. 961-1011.

Nieder, R., D.K. Benbi, and H.W. Scherer, Fixation and defixation of ammonium in soils: a review. Biol Fertil Soils, 2011. 47: p. 1-14.

Ünal, H., Başkaya, H.S., 1981. Toprak: Kimyası. Ankara Ünİ. Ziraat Fak. Yay No: 759, 144-232.

Phillips, I.R. and M. Greenway, Changes in water-soluble and exchangeable ions, cation exchange capacity, and phosphorus $(\max )$ in soils under alternating waterlogged and drying conditions. Comm. Soil Sci. Plant Anal, 1998. 29: 51-66.

Peech, M. and Bradfield, R., 1943. The effect of lime and magnesia on the soil potassium and on the absorption of potassium by plants. Soil Sci. 55: 37-48.

Pierre, W. H., 1947. The relation of potassium fixation to ammonium fixation. Soil Sci. Soc. Amer. Proc. 11: 155-160.

Sakin, E ve Yanardağ, I.H., 2019. Effect Of Applıcatıon Of Sheep Manure And Its B1ochar On Carbon Emıssions In Salt Affected Calcareous Soıl In Sanlıurfa Regıon Se Turkey. Fresenius Envir. Bull. 28(4):2550-2560

Sezen, Y., 1975. Doğu Anadolu'nun değişik yerlerinden alınan toprak örneklerinin Bitkiye potasyum sağlama durumları üzerinde bir araştırma. Atatürk Üni. Ziraat Falk. Yay No: 195, 2629. 
Sezen, Y., 1991. Toprak Kimyası. Atatürk Üni. Ziraat Fak. Yay. No: 127, 120-122.

Tüzüner, A., 1990. DTPA Ekstraksiyon Yöntemiyle Mikro element Tayini, Toprak ve Su Analiz Laboratuarı El Kitabı, Ankara. s. 56-60.

Welch, L F., 1958. Availability of nonexchangeable potassium and ammonium to plants and microorganisms. Iowa state Univ. P:1-170. https://lib.dr.iastate.edu/rtd/1655. 